Page $99-118$

\title{
EFFICIENCY OF SAVING AND CREDIT COOPERATIVE UNITS IN NORTH ACEH, INDONESIA
}

\author{
Ghazali Syamni, M. Shabri Abd. Majid \\ University of Malikussaleh, University of Syiah Kuala \\ syamni_ghazali@yahoo.com, mshabri@unsyiah.ac.id
}

\begin{abstract}
The purpose of this study is to measure and analyze the relative efficiency of saving and credit cooperative units in North Aceh, Indonesia. In this study, the selection of inputs and outputs to be analyzed by the Data Envelopment Analysis (DEA) was selected using the intermediation approach. The results showed that the overall saving and credit cooperative units in North Aceh, Indonesia have not operated fully efficient. This is indicated by the average of value of Malmquist Productivity Index which was still below one, but individually the study found that some cooperatives have operated efficiently, such as cooperative employee of PT Pupuk Iskandar Muda (Persero), KPN Kopebun, KPN Citra Guru, KPN Tunas and Kopbun Cut Mutia. These findings implied that more serious efforts should be made by the saving and credit cooperative units in North Aceh, Indonesia to improve the cooperative management efficiency levels by managing their capital and assets professionally.
\end{abstract}

Keywords: Efficiency; Cooperative; Saving; Credit; Data Envelopment Analysis

\begin{abstract}
Abstrak
Tujuan dari kajian ini ialah untuk mengukur dan menganalisis efisiensi relatif koperasi simpan pinjam di Aceh Utara, Indonesia. Metode analisis yang dipergunakan ialah dengan data envelopment analysis (DEA) dengan pendekatan intermediasi dalam pemilihan input-output. Hasil penelitian menunjukkan bahwa rata-rata koperasi simpan pinjam di Aceh Utara,, Indonesia belum sepenuhnya beroperasi secara efisien. Hal ini diindikasikan oleh nilai indeks produktivitas Malmquist secara rerata masih di bawah satu, akan tetapi secara individual ditemukan beberapa koperasi yang mampu beroperasi secara efisiensi, yaitu: Koperasi Karyawan PT Pupuk Iskandar Muda (Persero), KPN Kopebun, KPN Citra Guru, KPN Tunas, dan Kopbun Cut Mutia. Hasil penelitian ini menunjukkan bahwa perlu dilakukan usaya serius dalam meningkatkan efisensi koperasi simpan pinjam di Aceh Utara, Indonesia termasuk melalui peningkatan pengelolaan modal dan asset koperasi secara professional.
\end{abstract}

Kata Kunci: Efisiensi; Koperasi; Tabungan; Kredit; Data Envelopment Analysis

Received: May 5, 2016; Revised: August 10, 2016; Approved: September 5, 2016 


\section{INTRODUCTION}

Quantitatively, the development of cooperative units in Indonesia has been heading in a positive direction in the last few decades, although there have been some inactive cooperative units for various reasons. United Nations declared 2012 as the World Year of Cooperatives. Through a number 64/I36/20I2 resolution, the UN recognized the role of cooperatives, particularly in Indonesia, as organizations that have proved to survive in the midst of the 2008 global economic crisis. The cooperatives in Indonesia have contributed to enhance the economic growth, create jobs, reduce poverty, and improve the prosperity and welfare of the Indonesian. This is in line with the statement of DeVille et al. (2007) who stated that cooperatives have been an important part in the economic development of countries in the world, because cooperatives can generate revenue more realistic.

According to the Secretary of State Ministry of Cooperatives and SMEs, Muharram (2013), there were 192,443 cooperative units in Indonesia with an average growth rate of $6.72 \%$ per year as of May 2012. Annually, there were 170,4II units in $2009,177,482$ units in 2010 , and 188,181 units in 2011 , and there were about $26-27 \%$ inactive cooperative units. In Indonesia, the cooperative footing was not separated from the Act No. 25 of 1992 and now it has been refurbished by the Act No. 17 of 2012, which regulated all matters relating to the cooperative. The Birth of Law No. 17 of 2012 was a concern about the government's empowerment/capacity building of cooperatives in Indonesia.

In Indonesia, there were ten provinces that have the highest number of cooperatives. These provinces including the East Java (29,150 units), Central Java (26,604 units), West Java (23,848 units), North Sumatra (10,879 units), South Sulawesi (8,044 units), Jakarta (7,663 units), Aceh (7,079 units), Banten (6,056 units), North Sulawesi (5,766 units), and the East Kalimantan (5,338 units). Recently, the State Ministry of Cooperatives and SMEs has enhanced the roles of 9.017 Credit Unions/Financial Cooperative Services and 87.047 Shariah Cooperative Savings and Loans Unit/Islamic Financial Services Unit to provide micro financing services for the SMEs.

Based on the types of cooperative units, the largest number of cooperatives was the consumer cooperatives (75.68 percent), followed by the producer 
cooperatives (17.98 percent), the savings and loans cooperatives (4.53 percent), the marketing cooperatives (I.24 percent), and the services cooperatives (0.56 percent). The number of cooperative members was increased from $29,240,27$ I people (2009), $30,46 \mathrm{I}, \mathrm{I} 2 \mathrm{I}$ people (20I0), 30,849,9I3 people (20II), and 33,687,4I7 people (20I2). Meanwhile, the labor force of cooperatives increased from 357,330 people (2009), 358,768 people (2010), 377,238 people (20II) to 425,822 people (2012) (Muharram, 2013).

Based on the above background, this study empirically measures and analyzes the efficiency of saving and credit cooperative units in North Aceh, Indonesia. The reason of choosing the North Aceh as the case of the study was this region is simply one of the districts that have the highest number of cooperatives in the province of Aceh, with total of 521 cooperative units. The findings of the study are hoped to shed some lights to improve the welfare of the cooperative members in particular and society in general. Cooperatives are unique, where all members are the users of services provided by the cooperatives (Marwa and Aziakpono, 2014). For example, credit cooperatives (savings and loans) will provide full services to all members included in their cooperative association, or group they work and live together in the same neighborhood. The prospective members will be given consideration for credit and deposit back to the cooperatives after a successful attempt. It was also dismissed the issue of the application of the principles of classical economics that maximum profit motive, but rather the social purposes (Fried et al., 1993).

Royer and Smith (2007) said that the cooperatives would restore the earned income to its members, or the number of patrons that will be allocated to members and can also be saved for use as a future capital. Although cooperatives are not prioritizing profits, the cooperatives need to secure positive profits or revenues, known as the SHU (Sisa Hasil Usaha) so that cooperatives could maintain its viability and enhance business capabilities. According to Wahyuning (20I3), the cooperative is a company that should be able to stand alone to run its business activities to positive SHU. According to the Act No. 25 Article 45, Paragraph I of 1992, "the SHU is a cooperative income earned within one year reduced the costs, depreciation, and other obligations, including in the tax year concerned”. Income or cooperative SHU is highly dependent on two aspects, namely the financial and non-financial factors (Act No. 25, 
1992). Financial factor will increase if the cooperative has its own access to capital (savings, compulsory savings, reserves and grants), external capital (debt) that can come from members, other cooperatives or their members, Banks and other financial institutions, the issuance of bonds and other debt securities, other sources of legal and business volume of sales of goods or services to the cooperative. However, the growth of cooperatives is also influenced by the non-financial factor, such as the number of employees, number of members and their business units. Thus, although a cooperative has a good financial performance, but without supported by a good nonfinancial factor, the cooperatives certainly will not be able to meet their objectives to maximize the SHU, and this in turn would lead the cooperative goes into bankruptcy.

The SHU is not maximized with regard to the efficiency of an agency or institution of the cooperative. It is true in a cooperative, SHU is greatly influenced by aspects of financial and non-financial, but the problem is that every cooperative does not have the same capacity. The findings of this study on the cooperative level of efficiency are hoped to contribute towards enhancing the SHU of saving and credit cooperatives in the North Aceh, Indonesia. Furthermore, this study would identify cooperative which is considered an efficient and feasible to serve as a benchmark for future cooperative development. Specifically, the purpose of this study is to measure and analyze the relative efficiency of saving and loan cooperatives that are considered worthy to be a cooperative effort to empower benchmark in the future in the North Aceh district.

Many studies related to the efficiency of the financial services field of cooperative institutions using DEA have been published in various countries. For example, Ariyatne et al. (2006) examined the factors affecting the efficiency in the United States. Gomez (2006) and Lopez and Marcuello (2006) analyzed the efficiency of agricultural cooperatives in Spain, Lavado (2004) investigated the cooperatives in the electricity sector in the Philippines, Fandel (2003) analyzed the efficiency of cooperatives in the plantation sector in Slovakia. Fukuyama et al. (1999) and Dong and Featherstone (2004) analyzed the efficiency of the credit cooperatives in Japan and China, respectively. Khan et al. (2010) analyzed the efficiency of cooperatives and SMEs in Pakistan, Jayamaha and Mula (2010) investigated the efficiency of credit cooperatives 
in Sri Lanka, and Singh et al. (2000) investigated the efficiency of cooperatives of factories in India. Ludena (2010) investigated the efficiency cooperatives in agricultural sector in Latin America and the Caribbean region. Candemir et al. (20II) investigated the efficiency of Agricultural Sales Cooperatives Unions of Hazelnut (HASCUs) in Turkey. Doumpos and Zopounidis (20I2) investigated the efficiency of cooperative banks in Europe, namely: Germany, France, Italy, Spain, and Austria. Finally, Tesfamariam et al. (2013) and Marwa and Aziakpono (2014) investigated the efficiency of credit unions in Ethiopia Tanzania, respectively.

However, to the best of our knowledge, there have not been much researches exploring the efficiency levels of the cooperatives in the context of Indonesia using the Data Envelopment Analysis. The researches on cooperative performance in Indonesia have only used the regression model and the balanced scorecard approach or merely examined the performance of the cooperatives with a focus on the SHU. For example, Rusdarti (2009) examined the effect of the involvement of the builder, the ability of management and participation of members of the cooperatives' financial performance at the boarding school. Antara and Komenaung (2007) used a structural equation modeling approach to evaluate the performance of village cooperatives in the province of Bali. Purnomo et al. (2013), Sagala and Made (2012), Pudjilestari (1999) analyzed the performance of cooperatives based on the balanced scorecard approach. Wardhani (2013) analyzed the financial performance of savings and loan unit of the Employees Cooperative of Republic of Indonesia at the University of Brawjaya. Indrayati (2012) analyzed the performance of cooperative with CAMEL. Ayuk and Suyana (2013) studied the effect of number of members, number of deposits, loan amount and the amount of working capital on the performance of the saving and credit cooperatives in Badung, Bali Province.

Based on the above literature review, there have been none of the studies that have examined the efficiency of cooperatives in Indonesia, including Aceh by using the technique of Data Envelopment Analysis (DEA). Ikhsan (2013) analyzed the performance of cooperatives in Banda Aceh and Aceh Besar. Their researches only compared the average performance of the cooperatives from year to year, particularly in terms of their number of members, profitability, liquidity, and solvency. Lukman (20I I) studied the effect of the amount of equity and the amount of external capital to 
the SHU of the cooperatives in the Lhokseumawe, Aceh. This study is among the pioneer of the study that attempts to examine the efficiency of saving and credit cooperatives using the technique of DEA, particularly in Aceh, and in Indonesia at large.

To achieve the objective of the study, this research uses non-parametric approach of the Data Envelopment Analysis (DEA) with Malmquist Index. This study only focuses on the contribution of technical change, efficiency change, pure changes and changes in the scale of Total Factor Productivity (TFP).

This rest of the study is divided into 5 Sections, where Part I contains the introduction, Section 2 discusses the literature review, Section 3 highlights the research method, Section 4 provides the results of research and discussion, and finally the conclusion of the study is presented in the last section of the study.

\section{METHOD}

\section{Data Collection}

This study uses data from 15 saving and credit cooperative units in the North Aceh, Indonesia in accordance with the Law No. 17 of 2012 concerning the cooperatives. This study covers the period from 2009 until 2012. Sources of input and output data of the cooperatives were obtained from the report of office of Cooperatives and SMEs, North Aceh. The 15 cooperatives investigated in this study including Kopkar P.T. Pupuk Iskandar Muda (Persero), Primkoplres A. Utara, KPNKopebun, KJKS Samudra Pasai, KPN-Citra Guru, KJKS Dewantara, KPN Tunas, Kopwan Aneka Usaha, KJKS Arafah, Koptan Harkat Tani, Kopbun Cut Mutia, Primkoppau Satrad 23I, Kop. Jasa Ade Beurata, Kopwan Bagi Beusare, and Kopbun Sumber Tani.

\section{Input and Output Selection}

The selection of input and output to measure the efficiency and productivity of financial services institutions has been debatable (Sathye, 2003). There were two approaches in the literature to measure the input and output of the bank, which is called the production approach and intermediation approach (Berger and Humphrey, 1997). In the intermediation approach, the fund financial industry is seen as a mediator between savers/depositor and investor (Banker et al., 1984). Output is measured in the value of money and the total cost, including operating and interest expenses 
(Sealey and Lindley, 1977). Meanwhile, in the production approach, banks are described using input purchases to produce deposits and various other categories of bank assets. But loans and deposits can be considered as output and measured in a number of accounts. The approach is to consider that only the operating costs and does not include interest expense paid on deposits when the deposits used as the output. Berger and Humphrey (1997) suggested the intermediation approach as the best option to analyze the efficiency of the bank, while the production approach is used to measure the efficiency of the banks' branch. This is simply due to the bank management that aims to reduce not only the total cost and non-interest expenses, but it also involves the investment decisions. While the level of service, the number of branches only serve members to fund the placement process.

Tesfamariam et al. (2013) analyzed the efficiency of the 329 saving and loan cooperatives in Ethiopia. In their study, the total cost savings have been identified as inputs, while the loans and total revenue have been identified as outputs. While Sealey and Lindley (1977) that analyzed the efficiency of credit unions incorporating labor $\left(X_{1}\right)$, capital $\left(X_{2}\right)$, and deposits $\left(X_{3}\right)$ as inputs, and loans $\left(Y_{1}\right)$ and security investments $\left(Y_{2}\right)$ as the outputs. The two outputs are the main activities of the credit union. The loan is seen as the output of a traditional business activities and investment security is viewed as the output of other important business activities. Loans, securities, capital, and deposits are measured in billions of yen at the end of each fiscal year. Labor equals the number of full-time employees and capital is measured as the value of building assets, real estate, equipment, and payment for which construction has not been completed, and a security deposit and tangible. Deposits form a major part of the obligations of the credit cooperatives.

The selection of inputs and outputs in this study, apart based on previous studies, are based on the Cooperative Act, number 17 of 2012. Under the legislation included in the cooperative in addition to explaining the foundation, principles and articles of association, also explained about; membership, the cooperative (meeting of members, administrators, supervisors), capital, and deposits SHU in this context is the volume of business, types, levels and businesses, controlling and inspection, merger and consolidation, dissolution, empowerment, administrative sanctions, transitional provisions and cover. Of these, this study only selects 5 inputs and 2 outputs for 
Efficiency of Saving and Credit Cooperatives Unit.........

Ghazali Syamni, M. Shabri Abd Majid

measuring the efficiency of cooperatives in the North Aceh, Indonesia, as shown by the following Table I:

Table I: Input and Output Specification of the Saving and Credit Cooperatives in North Aceh, Indonesia

\begin{tabular}{|c|c|c|}
\hline Variables & Definition & $\begin{array}{l}\text { Input/ } \\
\text { Output }\end{array}$ \\
\hline Equity capital & $\begin{array}{l}\text { Equity capital comes from the owners and embedded in cooperative efforts for } \\
\text { a period of unlimited duration, among other things: savings, compulsory savings, } \\
\text { reserve funds, grants. }\end{array}$ & Input \\
\hline Foreign capital & $\begin{array}{l}\text { Foreign capital comes from outside the cooperative as a loan/debt aims to } \\
\text { improve working capital within a certain time period, include: members, other } \\
\text { cooperatives and/or its members, the issuance of bonds and other debt } \\
\text { securities, banks and other financial institutions, other legitimate sources. }\end{array}$ & Input \\
\hline $\begin{array}{l}\text { Total Management } \\
\text { Tool }\end{array}$ & $\begin{array}{l}\text { Total Management Tool cooperative organization fully responsible for the } \\
\text { management of cooperatives for the benefit and purpose Cooperative and the } \\
\text { Cooperative representing both inside and outside the court in accordance with } \\
\text { the provisions of the Articles of Association. }\end{array}$ & Input \\
\hline $\begin{array}{l}\text { Number of } \\
\text { Trustees }\end{array}$ & $\begin{array}{l}\text { Number of Trustees The person elected from and by the Members at the } \\
\text { Member Meeting. }\end{array}$ & Input \\
\hline $\begin{array}{l}\text { Number of } \\
\text { Members }\end{array}$ & Number of Members Cooperative is the owner and user services cooperatives. & Input \\
\hline $\begin{array}{l}\text { Total Business } \\
\text { Volume }\end{array}$ & $\begin{array}{l}\text { Total Business Volume of business of gross income (the amount of gross } \\
\text { income) earned by the cooperative during the accounting period }\end{array}$ & Output \\
\hline $\begin{array}{l}\text { Difference in } \\
\text { Operating Results }\end{array}$ & $\begin{array}{l}\text { Difference in Operating Results surplus or deficit Operating Results obtained } \\
\text { from the results of operations or earnings in any one financial year Cooperative } \\
\text { after deducting expenditure on various operating expenses }\end{array}$ & Output \\
\hline
\end{tabular}

\section{RESULTS AND DISCUSSION}

\section{Description of Input and Output}

This study explored the efficiency of the cooperative at 15 saving and credit cooperatives in North Aceh, Indonesia. Based on data obtained at the offices of Cooperatives and SMEs until 2013, not all saving and credit cooperatives in North Aceh have been active in accordance with the Law of Cooperative, No. 17 of 2012. In the Act No. 17 of 2012, a cooperative should not operate with multiple types of businesses. Forexample, a credit union only justified performing activities of savings and loan, and there should not conduct other types of businesses. Similarly, the production cooperatives are only allowed to run production activity. Viewed from the perspective of operational principles, the cooperatives in North Aceh have been operating with very diverse principles. Some are operated based on the Shariah, such as KJKS Samudra Pasai, KJKS Dewantara, KJKS Arafah, Cooperative Women Aneka Usaha, cooperative women Bagi Beusare, which belongs to the Air Force Prinkopau Satrad 
23I, a cooperative Harkat Tani and Cooperative Jasa Ade Berata. In addition, there is also a cooperative unit that provided not only savings and loans, but also provided other businesses, such as: Cooperative employees PT Pupuk Iskandar Muda (Persero), Primkop Polres North Aceh, Cooperative Kopebun (Plantation Office), Cooperative Kopebun Cut Mutia and Cooperative Sumber Tani.

In the selection of the input and output to measure the efficiency of the cooperatives, this study adopted the intermediation approach. Five inputs of equity capital, foreign capital, number of members, number management and number of supervisors, and two output of the SHU and business volume were respectively selected. The selection of the SHU as output is because the main purpose of the cooperative is to maximize the SHU during the accounting year, while the selection of business volume as the other output is simply due to the SHU was obtained based on the volume of business generated by the cooperatives during the accounting year.

Table 2. Descriptive Statistics of Inputs and Outputs the Saving and Credit Cooperatives in North Aceh, Indonesia

\begin{tabular}{lrrrrr}
\hline Variabel & Mean & Median & Maximum & Minimum & StdDev \\
\hline $\begin{array}{l}\text { Input } \\
\text { Equity }\end{array}$ & $1,468.9$ & 334,1 & $46,239.3$ & 18,5 & $5,946$. \\
$\begin{array}{l}\text { Foreign Capital (Millions } \\
\text { of IDR) }\end{array}$ & $1,031.6$ & 178,6 & $14,225.6$ & 0 & $3,072.7$ \\
Number of Members & - & - & 1.327 & 21 & \\
Number of Managers & 3.3 & 3 & 7 & 2 & 0.78 \\
Number of Supervisors & 2.9 & 3 & 3 & 0 & 0.50 \\
Output & & & & & \\
Volume (Millions of IDR) & 1.047 & 113 & 20,426 & 13 & $3,202.4$ \\
SHU (Millions of IDR) & 75,0 & 35 & 851.0 & $-1,2$ & 142,6 \\
\hline
\end{tabular}

Table 2 reports a description of the inputs and outputs of 15 units of saving and credit cooperatives in the North Aceh. According to Table 2, the average of SHU Cooperatives was IDR75 million, while the highest of IDR85I.0 million was belong to the Cooperative of PT. Pupuk Iskandar Muda (Persero), and the lowest was IDR-I.2 million, which is belong to Kopbun Sources Tani. While the average business volume was IDRI,04.7 billion, the highest business volume was IDR20,426 billion is belong to the Cooperative PT. Pupuk Iskandar Muda (Persero), the lowest of IDRI 3 million was owned by the cooperative of Prinkopau Satrad 231. Meanwhile, the highest 
number of cooperative members was amounting to I,327 members, while the lowest was as many as 21 members. Furthermore, the Cooperative of Jasa Ade Berata has 7 managers, while the Prinkopau Satrad 23I only has 2 managers. In addition, when viewed from the use of capital, it was shown that all the cooperatives used more of their own capital compared to the use of external capital. The equity capital of the cooperatives was ranging from IDRI8.5 million to IDR46.239 billion. Finally, the external capital of cooperatives was ranging from IDRO to IDR I4, 225.6 billion.

\section{Frontier Production and Efficiency Levels}

Table 3 reports the efficiency changes on 15 units of saving and credit cooperatives during the period of 2009-2012 in North Aceh with a comparison of Constant Returns to Scale (CRS) and Variable Returns to Scale (VRS). Both CRS can be assumed that the addition of $1 \%$ input will only increase output by $1 \%$ as well. While VRS, each additional of $1 \%$ of input, output can add larger/smaller than $1 \%$. CRS and VRS interpret the value of each unit of the cooperative are underlined in the frontier during the years of the study. Efficiency of a cooperative with the value of one indicates the cooperative efficient, while cooperatives which have a value of less than one is inefficient and cooperatives that have values greater than one indicates a more efficient cooperative.

Based on Table 3, cooperative of PT Iskandar Muda Pupuk (Persero), KPN Kopebun, KJKS Arafat and Kopbun Cut Mutia, Kopbun Sumber Tani were the efficient cooperative that has a value consistent with both CRS and VRS. Moreover, the Cooperative of Jasa Ade Beurata was not efficient in 2009 because it has a value of 0.390, while in 2010 onwards it become consistently efficient. These results demonstrated that not only efficiency for diverse business units of the cooperatives, but the single unit of cooperative was also efficient such as the Cooperative of Islamic Arafah. However, others cooperatives such as KJKS Samudera Pasai was slightly better in its efficiency compared to the KJKS Dewantara. Cooperative of Primkoppau Satrad 23I, cooperative of Kopwan Aneka Usaha have consistent efficiency based on the VRS, but not the CRS, while Kopwan Bagi Beusare was not efficient based on the CRS due to its low value, but based on the VRS it become efficient in the last three years. 
Table 3. Level of Efficiency Based on the Assumptions of Constant Returns to Scale (CRS) and Variable Returns to Scale (VRS)

\begin{tabular}{|c|c|c|c|c|c|c|c|c|c|}
\hline \multirow{3}{*}{\multicolumn{2}{|c|}{ NamaKoperasi }} & \multicolumn{8}{|c|}{ Years } \\
\hline & & \multicolumn{4}{|c|}{ CRS } & \multicolumn{4}{|c|}{ VRS } \\
\hline & & \multirow{2}{*}{$\begin{array}{l}2009 \\
1.000\end{array}$} & \multirow{2}{*}{$\frac{2010}{1.000}$} & \multirow{2}{*}{$\frac{2011}{1.000}$} & \multirow{2}{*}{$\begin{array}{l}2012 \\
1.000\end{array}$} & \multirow{2}{*}{$\begin{array}{l}2009 \\
1.000\end{array}$} & \multirow{2}{*}{$\frac{2010}{1.000}$} & \multirow{2}{*}{$\frac{2011}{1.000}$} & \multirow{2}{*}{$\begin{array}{l}2012 \\
1.000\end{array}$} \\
\hline I. & Kopkar P.T. PIM & & & & & & & & \\
\hline 2. & Primkop Polres A.Utara & 0.865 & 1.000 & 1.000 & 0.326 & 0.865 & 1.000 & 1.000 & 0.326 \\
\hline 3. & KPN-Kopebun & 1.000 & 1.000 & 1.000 & 1.000 & 1.000 & 1.000 & 1.000 & 1.000 \\
\hline 4. & KJKS Samudra Pasai & 1.000 & 0.322 & 1,000 & 1.000 & 1.000 & 0.323 & 1.000 & 1.000 \\
\hline 5. & KPN-Citra Guru & 0.984 & 0.742 & 1.000 & 1.000 & 1.000 & 0.742 & 1.000 & 1.000 \\
\hline 6. & KJKS Dewantara & 1.000 & 0.898 & 0.366 & 0.498 & 1.000 & 1.000 & 0.366 & 0.498 \\
\hline 7. & KPN Tunas & 0.221 & 0.152 & 0.266 & 1.000 & 0.221 & 0.284 & 0.533 & 1.000 \\
\hline 8. & Kopwan Aneka Usaha & 1.000 & 0.830 & 0.299 & 0.338 & 1.000 & 1.000 & 1.000 & 1.000 \\
\hline 9. & KJKS Arafah & 1.000 & 1.000 & 1.000 & 1.000 & 1.000 & 1.000 & 1.000 & 1.000 \\
\hline 10. & Koptan Harkat Tani & 0.265 & 0.186 & 0.424 & 0.120 & 0.265 & 0.192 & 0.480 & 0.124 \\
\hline II. & Kopbun Cut Mutia & 1.000 & 1.000 & 1.000 & 1.000 & 1.000 & 1.000 & 1.000 & 1.000 \\
\hline 12. & Primkoppau Satrad 23I & 1.000 & 0.417 & 1.000 & 0.509 & 1.000 & 1.000 & 1.000 & 1.000 \\
\hline 13. & Kop.Jasa Ade Beurata & 0.390 & 1.000 & 1.000 & 1.000 & 1.000 & 1.000 & 1.000 & 1.000 \\
\hline 14. & Kopwan Bagi Beusare & 1.000 & 0.252 & 0.583 & 0.532 & 1.000 & 1.000 & 1.000 & 0.547 \\
\hline 15. & Kopbun Sumber Tani & 1.000 & 1.000 & 1.000 & 1.000 & 1.000 & 1.000 & 1.000 & 1.000 \\
\hline & Mean & 0.848 & 0.720 & 0.796 & 0.755 & 0.890 & 0.836 & 0.892 & 0.833 \\
\hline
\end{tabular}

Based on Table 3, the cooperative of Harkat Tani have values of CRS and VRS were not efficient. Furthermore, the cooperative of Citra Guru was slightly better efficiency compared to the CRS and VSR of the cooperative of employees Tunas. From Table 3, we can witness that there was ample room available for the cooperatives to improve their efficiency levels both based on the CRS and VRS assumptions. The cooperative of Primkop Polres Aceh Utara in 2009 and 2012 had a value of CRS and VRS at 0.865 and 0.326 , meaning that in those years this cooperatives could still improved its efficiency level in 2009 and 2012 amounted to 0.135 (13.5\%) and 0.674 (67.4\%). Similarly, for KJKS Samudera Pasai in 2010 that the value of CRS and VRS was 0.32 , meaning that the KJKS need to increase the input of $0.68(68 \%)$ to produce better output so that it become consistently efficiency. The same thing can be seen for the Cooperative of Jasa Ade Beurata where in 2009 the value of the VRS was 0.390, meaning that the cooperatives need to add input to make the cooperative consistently 
efficiency. In other words, cooperatives need to add enough additional inputs either from their own capital or from external capital in order to produce better output to make the cooperative becoming consistently efficiency. The same is true for other cooperatives that have not shown a value of one both for the CRS and VRS.

The findings from Table 3 could also be interpreted as the percentage of potential maximum output level that is obtained from a variety of inputs used. For example, the cooperatives of Kopwan Bagi Beusare and Kopwan Jasa Ade Beurata, in 2010 resulted in $83 \%$ and $25.2 \%$ of their potential output, respectively based on the CRS. But the value of VRS of the two cooperatives was $100 \%$ in the same year. Overall, the average efficiency of the saving and credit cooperatives based on both CRS and VRS have decreased slightly from 2009-20I2. However, the average efficiency of cooperatives using the VRS was slightly higher than the CRS. The results of the overall assessment showed better efficiency based on the CRS in 2009, while the VRS is more efficient in $201 \mathrm{I}$.

\section{Individual Performance Credit Unions, 2009-20 I 2}

The study reported the performance of saving and credit cooperatives in years 2009-2012 based on the changes in two components, namely technical change and efficiency change. As is known, efficiency component consists of; pure efficiency, scale efficiency with a standard of measurement is one. In other words, if the results of both the efficiency value are less than one, then it is said to experience a decrease in efficiency compared with the previous period. Conversely, if the value is greater than one, it shows an increase in the level of efficiency.

In general, Total Factor Productivity (TFP) of all cooperatives examined in this study showed a fluctuating value. Of the 15 cooperatives under study, there were two cooperatives that their TFP declined in 2009-2010, namely the Cooperative of PT. Pupuk Iskandar Muda and Cooperative of Kopwan Bagi Beusare, respectively with the value of $26.2 \%$ and $60.1 \%$. While in the period $2010-20 \mathrm{II}$ and $20 \mathrm{II}-20 \mathrm{I}$, there was an increase of $31.7 \%$ and $60.1 \%$ in the Cooperative of PT Pupuk Iskandar Muda (Persero) and $10.5 \%$ and $4.1 \%$ for the cooperative of Kopwan Bagi Beusare. TFP changes in the cooperatives determined by the efficiency of the technique (Techch) just to the Cooperative PT. Pupuk Iskandar Muda (Persero), not by efficiency (Effch), which is, indicated by the second component of pure efficiency (Pech) and scale 
efficiency (Sech) unchanged. In the meantime, the Cooperative of Bagi Beusare, its TFP changes due to technical efficiency contribution (Techch) and efficiency (Effch). It Techch declined in $201 \mathrm{I}$ amounted to $52.2 \%$, further efficiency (Effch) amended in 2010 amounted to $74.8 \%$ and in 2012 by $8.7 \%$. Effch changes occurred due to changes in pure efficiency scale efficiency in 2012 or 2010 , respectively by $45.35 \%$ and $74.8 \%$.

The declines of TFP in $201 \mathrm{I}$ were also occurred for the cooperatives of KPN Tunas, KPN Kopebun, and Kopbun Cut Mutia. All these cooperatives, their TFP has declined respectively by $33 \%, 8.7 \%$ and $29.2 \%$ in $2010-2011$. KPN Kopebun's TFP changes are caused by changes in technical efficiency (Techch), while the efficiency was not changed at all. Technical changes rose in the period 2009-2010 and the period $20 \mathrm{II}-20 \mathrm{I} 2$ by $45.9 \%$ and $29.3 \%$, respectively, while in $20 \mathrm{I} 0-20 \mathrm{II}$ there was a decrease of $33.0 \%$. KPN Cut Mutia's TFP changes are caused by changes in Techch, and was not in Effch. The Techch of KPN Cut Mutia value has increased in the period between 2009-2010 and $2011-2012$ by $49.3 \%$ and $89.0 \%$, respectively. However, in the period 2010-20II fell by $29.2 \%$. While the Cooperative of Tunas TFP changes occurred because of changes of Techch and Effch. Techch except in 2010-20II, which fell by $48.0 \%$, during the periods $2009-2010$ and $2011-2012$ they have increased by $80.8 \%$ and $39.9 \%$. Unlike the $2009-2010$ periods in which Effch declined by $21.3 \%$, on the other period they have increased by $75.5 \%$ and $76.1 \%$. Increased in Effch was generally caused by changes in Pech, i.e. $28.7 \%, 87.8 \%$ and $87.5 \%$ in the period $2009-2010,2010$ $20 \mathrm{II}$ and $20 \mathrm{II}-20 \mathrm{I} 2$.

Unlike other periods, the cooperative of Jasa Ade Beurata TFP decreased only in 20I I-20I 2 was $42.4 \%$. The change was due to an increase in efficiency, Techch and Effch. Effch has increased by $56.66 \%$ in $2009-2010$, but the other has not changed. Except for the period of $201 \mathrm{I}-2012$ in which Techch fell by $42.6 \%$, but in the other period has increased by $14.6 \%$ and $10.3 \%$. While the Cooperative of Citra Guru is a cooperative that has an increased value due to changes in TFP, Techch, and Effch. Effch of $2009-2010$ fell $24.7 \%$ and $34.9 \%$ increases in the next period and did not change in the next period. Effch changes due to changes in the Pech by $25.8 \%$ in $2009-2010$ and $34.9 \%$ in $2010-2011$ increased, but sech rose only in the period $2009-2010$ by $1.6 \%$. While Techch rose in the period 2009-2010 amounted to $64.0 \%$, declined by $28.2 \%$ and the subsequent period up $2.2 \%$ return period $20 \mathrm{I} \mathrm{I}-20 \mathrm{I} 2$. 
As for the cooperatives of KJKS Samudera Pasai, KJKS Dewantara and KJKS Arafah, the changes in TFP have changed inconsistently in each period. For KJKS Samudera Pasai, there was an increase in efficiency in the period 2010-201 I amounted to $84.7 \%$, and KJKS Arafah, KJKS Dewantara increased TFP in 20I I-20I2 amounted to 94.0\% and I5.8\%. The third KJKS TFP changes were due entirely to changes in Techch and Effch. Effch KJKS Samudera Pasai has decreased by $67.8 \%$ in 2009-20I0 and in the period 2010-20I I increased by $10.8 \%$ and did not change in the period $20 \mathrm{II}-20 \mathrm{I} 2$ and Techch increased by $39.6 \%$ during $2009-2010$, but the two later periods fall in the range of $40.6 \%$ and $14.5 \%$. The change was due to a decrease in the efficiency of pure efficiency Pech in 2009-2010 amounted to 67.7\%. Furthermore, there has been a change Effch in KJKS Dewantara, increased by $36.0 \%$ in $201 \mathrm{I}-2012$ and previous two periods decreased by $10.2 \%$ and $59.3 \%$. Effch changes caused by a decrease of $36.6 \%$ in Pech during the 20I0-20II, and the $20 \mathrm{II}-20 \mathrm{I} 2$ periods Pech's rose by $36.0 \%$. Likewise sech decreased $10.2 \%$ during $2009-2010$ and $2010-2011$ rose by $11.3 \%$. While the changes have increased Techch 20I0-20II and 20II-20I2, respectively $5.1 \%$ and 42.7\%, but decreased in $2009-2010$ by $24.0 \%$. While KJKS Arafah TFP changes caused only by changes in the efficiency of the technique, which declined in the period 2009 2010 and $2010-2011$ by $5.1 \%$ and $17.2 \%$.

The cooperative of Aneka Usaha in the period 201 I-2012, its TFP increased by $38.1 \%$ after a period of $2009-2010$ and $201 \mathrm{I}-2012$ decreased by $25.1 \%$ and $66.4 \%$. The increase is due to changes Effch and Techch in 20II-2012 respectively increased by 13.2\% and 39.9\%. While Koptan Harkat Tani and Primkoppau Satrad 23I is only the second cooperative TFP increased in 2010-201 I, which, increased by $63.1 \%$ and $14.8 \%$. Both of these cooperatives found Effch $2009-2010$ period decreased by $29.6 \%$ and $58.9 \%$, the period $201 \mathrm{I}-2012$ was also decreased by $71.6 \%$ and $49.1 \%$. Only the period 20I0-20II increased by $127.6 \%$ Effch and $140.1 \%$. On the side Techch, only Harkat Farmer cooperatives increased by $12.1 \%$.

All of the samples, Primkop Polres A.Utara and Kopbun Sumber Tani, both of them do not have TFP value smaller than I or not a decrease in the level of efficiency. During the study period, Primkop Polres Aceh Utara has decreased by $100 \%, 45.7 \%$ and $54.2 \%$. It occurs due to an increase in the period 2009-2010 Effch of $15.6 \%$, no change in 20I0-20II and in 20II-20I2 the scaling of 67.4\%. Techch has decreased in 
the period $2009-2010$ amounted to $100 \%$, also down $45.7 \%$ from 2010 to $201 \mathrm{I}$ and the period 20I I-20I2 increased by 40.5\%. While TFP for Koptan Sumber Tani over three study periods also decreased respectively by $100 \%, 36.7 \%$ and $26.8 \%$. The decline in TFP is entirely due to the decrease Techch. Techch value in the third period of the period was down $100 \%, 36.7 \%$ and $173.2 \%$ increase, not because Effch that all values are equal to one.

\section{Productivity Credit Unions in North Aceh Wholly}

Table 4 shows the performance Productivity Malmquist index of saving and credit cooperatives in North Aceh, Indonesia. Total Productivity (TFP) has changed in both the level of efficiency and technical efficiency. Based on Table 5, on the average, saving and credit cooperatives in North Aceh have not shown towards more efficient. We could see that the value of the average level of efficiency and technical efficiency was still around less than one.

Table 4. Summary of Malmquist Productivity Index of Cooperatives Means, 2009-20I2

\begin{tabular}{clccccc}
\hline Number & Name of Cooperatives & Effch & Techch & Pech & Sech & TFPch \\
\hline I & Kopkar PT PIM & 1.000 & 1.159 & 1.000 & 1.000 & I.I59 \\
2 & Primkoppol Polres A. & 0.723 & 1.020 & 0.723 & 1.000 & 0.832 \\
& Utara & & & & & \\
3 & KPN-Kopebun & 1.000 & $1.08 \mathrm{I}$ & 1.000 & 1.000 & $1.08 \mathrm{I}$ \\
4 & KJKS Samudra Pasai & 1.000 & 0.892 & 1.000 & 1.000 & 0.892 \\
5 & KPN-Citra Guru & 1.005 & 1.064 & 1.000 & 1.005 & 1.069 \\
6 & KJKS Dewantara & 0.792 & 1.044 & 0.792 & 1.000 & 0.828 \\
7 & KPN Tunas & 1.655 & 1.096 & 1.655 & 1.000 & 1.814 \\
8 & Kopwan Aneka Usaha & 0.697 & 0.962 & 1.000 & 0.697 & 0.670 \\
9 & KJKS Arafah & 1.000 & 0.973 & 1.000 & 1.000 & 0.973 \\
I0 & Koptan Harkat Tani & 0.769 & 1.037 & 0.777 & 0.989 & 0.797 \\
II & Kopbun Cut Mutia & 1.000 & 1.259 & 1.000 & 1.000 & 1.259 \\
I2 & Primkoppau Satrad 23I & 0.798 & 0.776 & 1.000 & 0.798 & 0.787 \\
I3 & Kop. Jasa Ade Beurata & 1.369 & 0.900 & 1.000 & 1.369 & 1.232 \\
I4 & Kopwan Bagi Beusare & 0.810 & 0.952 & 0.818 & 0.991 & 0.77 I \\
I5 & Kopbun Sumber Tani & 1.000 & 0.987 & 1.000 & 1.000 & 0.998 \\
\hline
\end{tabular}

However, judging from their respective cooperatives, there are some cooperatives that have increased their levels of efficiency, such as: cooperative of PT Pupuk Iskandar Muda (Persero), KPN Kopebun, KPN Citra Guru, and Kopbun Cut Mutia. Although these cooperatives have not experienced an increase in the level of high efficiency and sustainable and even changes in technical efficiency has not been a good and stable, but the overall efficiency of the four cooperatives have recorded a steady increase. The percentage change in the level of efficiency and technical efficiency 
respectively unchanged, but only the KPN Citra Guru that recorded an increase in efficiency levels between $0.5 \%$ to $65.5 \%$, and technically, the efficiency increases ranging from $6.4 \%$ to $25.9 \%$. KJKS Samudera Pasai has decreased the level of technical efficiency of $10.8 \%$ and efficiency levels did not change, KJKS Dewantara recorded an increase in the level of technical efficiency of $0.44 \%$ and a decrease in the efficiency level of $\mathbf{2 0 . 8} \%$, while the rate of Arafah KJKS efficiency did not change, but for technical efficiency has decreased by $2.7 \%$. The same was experienced by the cooperative of Koptan Harkat Tani and cooperative of Jasa Ade Berata. In addition, several other cooperatives showed no increase in technical efficiency, and even they have experienced a decrease in the level of efficiency, such as Pripkop Polres A.Utara, Primkoppau Satrad 23I and Kopbun Sumber Tani. Meanwhile, the cooperatives of Aneka Usaha and Kopwan Kopwan Bagi Beusare showed a decrease in the level of efficiency and technical efficiency.

The findings of this study are consistent with the results of researches by López and Marcuello (2006) and Ludena (2010) who mentioned that the difference in the efficiency of the studied sample. López and Marcuello (2006) found that a decrease in efficiency among cooperatives in the Philippines due to the management of cooperative management is still done well in traditional sales activities as well as in the capital and asset management. While Ludena (2010) states that the level of efficiency of cooperatives in Latin America and the Caribbean is much better because it is supported by the positive contribution of the agricultural sector to economic growth in the country. The findings of this study are similar to a cooperative where plantations have better efficiency as Kopebun KPN, KPN Tunas and Kopbun Cut Mutia. Although there are also other cooperatives that are not engaged in the agricultural sector, such as Kopkar PT Pupuk Iskandar Muda (Persero) and KPN Citra Guru has a good level of efficiency as well. Of course, this happens because the cooperative management is done by the employees and teachers are relatively more professional compared to other cooperative owned by the community at large. The same findings also documented by Dong and Featherstone (2004), Ariyaratne (2006) and Tesfamariam (2013) who found that the result of differences in efficiency between the studied cooperatives among each other. 
The results of this study provide some efficiency important implications for development policy makers and managers of cooperatives. Policy makers and managers can figure out a cooperative which have been operated efficiently or not. Cooperatives with high efficiency and productivity levels was due to their ability to use of minimal inputs to generate optimal outputs as reflected in the value of pure efficiency, scale efficiency, efficiency and technical efficiency. Meanwhile, the enactment of Law No. 17 of 2012 requires that policy makers and managers of cooperatives to manage the cooperative in accordance with government directives.

\section{CONCLUSIONS}

This study measured and analyzed the relative efficiency levels of saving and credit cooperatives in North Aceh, Indonesia during the period 2009 to 2012 by using a non-parametric approach, Data Envelopment Analysis. The input variables used are their own capital, foreign capital, number of members and number of board while the output variables are the volume of business and the SHU. The cooperatives in North Aceh, Indonesia has not fully operate efficiently, it is indicated by the average value of Malmquist Index values of less than one. Nevertheless, there are some individual cooperative that have been operated efficiently during the study period. Cooperatives should enhance their ability to use of minimal inputs to generate optimal outputs in accordance with government directives.

This study has the limitations of the use of the data and the types of cooperative. In addition, the cooperatives that were examined in this study had different number of business units, where some cooperatives have only one business unit and some other have more than one business units. Thus, future researches on the efficiency and productivity of the cooperatives are advised to use the data derived from the audited financial statements of the cooperatives with the same number of business units, operating in similar sector of business.

\section{REFERENCES}

Antara, M.K. \& A. Guntur. (2007). Kinerja Koperasi Unit Desa di Provinsi Bali: Pendekatan Structural Equation Model. Jurnal SOCA: Socio-Economic of Agriculturre and Agribusiness, Vol.7, No. 3, Pp. I-29. 
Ariyaratne, B.C. et.al. (2006). What Determines Productivity Growth of Agricultural Cooperatives? Journal of Agricultural and Applied Economics, Vol. 38, No. I, Pp. 4759.

Ayuk, N.M.T. \& U.I.M. Suyana. (20I3). Pengaruh Jumlah Anggota, Jumlah Simpanan, Jumlah Pinjaman dan Jumlah Modal Kerja terhadap Sisa Hasil Usaha Koperasi Simpan Pinjam di Kabupaten Badung Provinsi Bali. E-Jurnal Ekonomi dan Bisnis Universitas Udayana, Vol. 2, No.9, pp. 629-646

Banker, R.D. et.al. (1984). Some Models for Estimating Technical and Scale Inefficiencies in Data Envelopment Analysis. Management Science, Vol. 30, Pp. 1078-1092.

Berger, Anand Humphrey, DB. (1997), 'Efficiency of Financial Institutions; International Survey and Directions for Future Research', European Journal of Operational Research, Vol. 98, No. 2, Pp. 175 - 212.

Candemir, M. et.al. (20II). Technical efficiency and total factor productivity growth in the hazelnut agricultural sales cooperatives unions in Turkey. Mathematical and Computational Applications, Vol. 16, No. I, Pp. 66-76

Deli. A. \& A.E. Ikhsan. (20II). Analisis Kinerja Koperasi di Kota Banda Aceh dan Aceh Besar, Sains Riset, Vol.I, No. 2, pp.I-16.

Ikhsan, A.E. (20I3). Analisis Kinerja Koperasi. Pekbis Jurnal, Volume 5, No I, PP. 42-50. DeVille, K.C. et.al. (2007). Farmer Cooperative Statistics, 2006. In: R.D. United States Department of Agriculture, Editor, Washington,. D.C.

Dong, F. \& A. Featherstone. (2004).Technical and Scale Efficiencies for Chinese Rural Credit Cooperatives: A Bootstrapping Approach in Data Envelopment Analysis, Working Paper, No. 04-WP 366.

Doumpos, M. \& C. Zopounidis. (2012). Efficiency and Performance Evaluation of European Cooperative Banks, Working Paper, No. 05.

Fandel, P. (2003). Technical and Scale Efficiency of Corporate Farm in Slovakia. Agric. Econ. Czech, Vol. 49, No.8. pp. 375-383.

Fried, H. O. et.al. (1993). Evaluating the Performance of U.S., Credit Unions. Journal of Banking and Finance, Vol. 17, pp. 25I-265.

Fukuyama, H. et.al. (1999). Efficiency and Ownership: Evidence from Japanese Credit Cooperatives. Journal of Economics and Business, Vol. 5I, pp. 473-487. 
Gómez, E.G. (2006). Productivity and Efficiency Analysis of Horticultural CoOperatives. Spanish Journal of Agricultural Research, Vol. 4, No. 3, Pp. 191-20I.

Indrayati, Kris. (2012). Kinerja Keuangan Berdasarkan Metode CAMEL pada Koperasi Simpan Pinjam. Management Analysis Journal, Vol.I, No.2, Pp. I-7.

Jayamaha, Ariyarathna dan M.J. Mula. (2010). Financial Practices and Efficiency of Cooperative Rural Banks In Sri Lanka. ICBI 2010-University of Kelaniya, Sri langka Khan, Z. et.al. (2010). Commercial Verses Cooperative Microfinance Program: An Investigation of Efficiency, Performance and Sustainability. The Dialogue, Volume V. Issue 2, Pp. 69-83

Lavado, R. (2004). Benchmarking the Efficiency of Philipines Electric Cooperatives Using Stochastic Frontier Analysis and Data Envelopment Analysis, East-West Center, Working Papers, No. 8, International Graduate Student Conference Series.

López, A. \& C. Marcuello. (2006). Agricultural Cooperatives and Economic Efficiency. NewMedit: A Mediterranean Journal of Economics, Agriculture and Environment, Vol. 5, No. 3, pp. 16-22.

Ludena, C. (2010). Agricultural Productivity Growth, Efficiency Change and Technical Progress in Latin America and the Caribbean. Inter-American Development Bank. Research, Dept. II. Title. III. Series.

Lukman. (20II). Pengaruh Jumlah Modal Sendiri dan Jumlah Modal Luar terhadap Sisa Hasil Usaha melalui Variabel Volume Usaha pada Koperasi-Koperasi di Kota Lhokseumawe. Ekonis, Vol. I0, No. I, PP. I-II.

Marwa, N. \& M. Aziakpono. (20l4). Efficiency and Profitability of Tanzanian saving and Credit Cooperatives: Who is a Star? Journal of Economics and Behavioral Studies, Vol.6, No. 8, pp. 658-669.

Pudjilestari, S.I. (1999). Pengukuran Kinerja Koperasi: Studi Kasus pada Koperasi Pegawai Departemen Koperasi, Pengusaha Kecil dan Menengah dengan Pendekatan Balanced Scorecard. (Unpublished Thesis). Depok: Universitas Indonesia.

Royer, J.S. \& D.B. Smith. (2007). Patronage Refunds, Producer Expectations, and Optimal Pricing by Agricultural Cooperatives. Journal of Cooperatives, Vol. 20, pp. I-I6. 
Rusdarti. (2009). Pengaruh Keterlibatan Pembina, Kemampuan Pengurus dan Partisipasi Anggota terhadap Kinerja Keuangan Koperasi Pondok Pesantren. Jejak, Vol. 2, No. I, pp. 8-2I.

Sagala, M. et.al. (20/2). Kinerja Koperasi Unit Desa UlunTanjung Desa Kerobokan, Kecamatan Kuta Utara, Kabupaten Badung (Ditinjau dari Balanced Scorecard). EJurnal Agribisnis dan Agrowisata, Vol. I, No. 2, pp. 69-77.

Sathye, M. (2003). Measuring Productivity Changes in Australian Banking: An Application of Malmquist Indices. Managerial Finance, Vol. 28, 48-59.

Sealey, C. Jr. \& J.T. Lindley. (1977). Inputs, Outputs, and a Theory of Production and Cost at Depository Financial Institutions. Journal of Finance, Vol. 32, Pp. I25I1266.

Singh, S. et.al (2000). Efficiency and Productivity Analysis of Cooperative Dairy Plants in Haryana and Punjab States of India, Working Paper Series in Agricultural and Resource Economics, No. 2000-2, Pp.I-I8.

Tesfamariam, K. et.al. (20/3). Relative Efficiency of Rural Saving and Credit Cooperatives: An Application of Data Envelopment Analysis, International Journal of Cooperative Studies, Vol. 2, No. I, pp. 16-25.

Wardhani, N.L. (20I3). Analisis Kinerja Keuangan Unit Simpan Pinjam Koperasi Pegawai Republik Indonesia Universitas Brawijaya. Jurnal Ilmiah Mahasiswa FEB, Universitas Brawijaya, Vol. I, No. 2, pp. I-I0.

Wahyuning, T. (20I3). Beberapa Faktor yang Mempengaruhi Sisa Hasil Usaha (SHU) di KPRI “Bina Karya” Balongpanggang-Gresik. Jurnal Ekonomi Bisnis, Vol. I, No. I, PP. I-I8. 